\title{
Pharmacologic Characterization of ALD403, a Potent Neutralizing Humanized Monoclonal Antibody Against the Calcitonin Gene-Related Peptide ${ }^{\mathbb{\$}}$
}

\author{
Leon F. Garcia-Martinez, Carol J. Raport, Ethan W. Ojala, Benjamin Dutzar, Katie Anderson, \\ Erica Stewart, Brian Kovacevich, Brian Baker, Jens Billgren, Michelle Scalley-Kim, \\ Charlie Karasek, Dan Allison, and John A. Latham
}

Lundbeck Seattle BioPharmaceuticals, Inc., Bothell, Washington

Received February 20, 2020; accepted April 24, 2020

\begin{abstract}
ALD403 is a genetically engineered, humanized immunoglobulin G1 monoclonal antibody that inhibits the action of human calcitonin gene-related peptide (CGRP). Clinical trial data indicate that ALD403 is effective as a preventive therapy for migraine and has an acceptable safety profile. For preclinical characterization of ALD403, rabbit antibodies targeting $\alpha$-CGRP were humanized and modified to eliminate fragment crystallizable $(\mathrm{Fc}) \gamma$ receptor $(\mathrm{Fc} \gamma \mathrm{R})$ and complement interactions. The ability of ALD403 to inhibit CGRP-induced cAMP production was assessed using a cAMP bioassay (Meso Scale Discovery). The $\mathrm{IC}_{50}$ for inhibition of cAMP release was 434 and 288 pM with the rabbit-human chimera antibody and the humanized ALD403, respectively. ALD403 inhibited $\alpha$-CGRP binding with an $\mathrm{IC}_{50}$ of $4.7 \times 10^{-11}$ and $1.2 \times 10^{-10} \mathrm{M}$ for the $\alpha$-CGRP and AMY1 receptors, respectively. ALD403 did not induce
\end{abstract}

antibody-dependent cellular cytotoxicity or complementdependent cytotoxicity and did not stably interact with any of the Fc $\gamma R$ mediating these functions, exhibiting only weak binding to Fc $\gamma$ RI. ALD403 significantly lowered capsaicininduced blood flow responses in rodents at all time points starting at 5 minutes postapplication in a dose-dependent manner. In conclusion, ALD403 is a potent functional ligand inhibitor of $\alpha$-CGRP-driven pharmacology.

\section{SIGNIFICANCE STATEMENT}

$\alpha$-Calcitonin gene-related peptide blockade by ALD403 was assessed via radiolabeled ligand displacement, in vitro inhibition of cell signaling, and in vivo inhibition of capsaicin-induced vasodilation. Lack of engagement of fragment crystallizablemediated immune-effector functions by ALD403 was shown.

\section{Introduction}

Migraine is a paroxysmal neurologic disorder of moderate to severe headache associated with physiologic disruptions of neurologic and sensory function (Headache Classification Committee of the International Headache Society, 2018). Migraines often begin in adolescence or early adulthood and continue over the decades of an individual's life (Bille, 1997). Migraine is the most prevalent neurologic disorder for which medical treatment is sought and is considered the sixth leading cause of disability worldwide (Steiner et al., 2013, 2018; GBD 2016 Disease and Injury Incidence and Prevalence Collaborators, 2017). The debilitating nature of migraine

This research was fully funded by H. Lundbeck A/S, Copenhagen, Denmark. Disclosure Summary. All authors were employed by Lundbeck Seattle BioPharmaceuticals, Inc. (FKA Alder BioPharmaceuticals, Inc.), or were previous employees, at time of manuscript preparation.

Primary laboratory of origin: Lundbeck Seattle BioPharmaceuticals, Inc., Bothell, WA.

https://doi.org/10.1124/jpet.119.264671.

S This article has supplemental material available at jpet.aspetjournals.org. makes preventive treatment an attractive option (Lipton and Silberstein, 2015). It is estimated that up to $40 \%$ of adults with frequent episodes of migraine and nearly all with chronic migraine would benefit from preventive therapy (Lipton et al., 2007). In large measure, this is due to poor tolerability, lack of efficacy, and poor adherence to traditional acute migraine treatments (Loder, 2010; Lipton and Silberstein, 2015; Russo, 2015; Obermann and Holle, 2016; Lukacs et al., 2017). These observations suggest an ongoing need for new therapeutic options for migraine prevention that are safe, efficacious, and well tolerated (Silberstein et al., 2012; Lipton and Silberstein, 2015).

Although the pathophysiology of migraine is complex and incompletely understood (Noseda and Burstein, 2013; Pietrobon and Moskowitz, 2013), calcitonin gene-related peptide (CGRP) has emerged as an important target for prevention of migraine (Wrobel Goldberg and Silberstein, 2015). CGRP is abundant in trigeminal neurons, which elicit nociceptive signaling pathways involved in migraine (May and Goadsby, 1999; Buzzi et al., 2003). In addition to being implicated in

ABBREVIATIONS: ADCC, antibody-dependent cell-mediated cytotoxicity; ADCP, antibody-dependent cell-mediated phagocytosis; ATCC, American Type Culture Collection; BSA, bovine serum albumin; CDC, complement-dependent cytotoxicity; CDR, complementarity-determining region; CGRP, calcitonin gene-related peptide; ECL, electrochemiluminescence; Fc, fragment crystallizable; Fc $\gamma \mathrm{R}$, Fc $\gamma$ receptor; mAb, monoclonal antibody; MSD, Meso Scale Discovery; NHS, N-hydroxysuccinimide; RU, response unit; TK, toxicokinetic. 
pain transmission and neuronal sensitization in both peripheral and central pain pathways (Durham, 2006), CGRP has been implicated in migraine-related vasodilation and triggering of neurogenic inflammation (Hostetler et al., 2013). A role for CGRP in migraine is further supported by data showing that intravenous infusions of CGRP can induce migraine-like headaches in individuals susceptible to migraine (Lassen et al., 2002; Hansen et al., 2010). Furthermore, many pharmacological agents used as acute or preventive treatment of migraine are known to inhibit the actions of CGRP (Edvinsson et al., 2018).

Small-molecule CGRP-receptor antagonists (gepants) were the first agents to demonstrate CGRP-directed inhibition of migraine, originally targeted as acute therapy (Tepper, 2018). Over the past few years, research efforts in migraine prevention have focused on inhibiting CGRP or its receptor through the use of monoclonal antibodies (mAbs), which have several advantages over small-molecule antagonists and alleviate safety concerns (Pellesi et al., 2017; Edvinsson, 2018b; Edvinsson et al., 2018). Monoclonal antibodies may be more target-selective, do not easily cross the blood-brain barrier, and are typically degraded by proteolysis rather than by metabolism via cytochrome P450 enzymes and thus are not associated with drug-drug interactions resulting from hepatic metabolism (Ferri et al., 2016).

ALD403 (eptinezumab) is an IgG1 monoclonal antibody that binds human CGRP and was designed to avoid fragment crystallizable $(\mathrm{Fc}) \gamma$ receptor $(\mathrm{Fc} \gamma \mathrm{R})$ and complement interactions via a mutation on the canonical N-linked glycosylation site N297 in its Fc region (Dorokhov et al., 2016; Saxena and $\mathrm{Wu}, 2016$; Baker et al., 2017; Mimura et al., 2018). A randomized, double-blind, placebo-controlled, exploratory, proof-of-concept phase II trial found a single intravenous administration of ALD403 to be generally safe and effective in reducing monthly headache days (mean change from baseline in monthly headache days vs. placebo after 5-8 weeks: -1.0 , $95 \%$ confidence interval -2.0 to 0.1 ; one-sided $P=0.0306)$ in patients with frequent episodic migraines (Dodick et al., 2014). In a phase IIb, parallel-group, double-blind, randomized, placebo-controlled, dose-ranging clinical trial of ALD403 in patients with chronic migraine, where the primary endpoint was $\geq 75 \%$ migraine responder rates, the doses of $300,100,30$, and $10 \mathrm{mg}$ of ALD403 resulted in $33.3 \%, 31.4 \%, 28.2 \%$, and $26.8 \%$ reduction, respectively, compared with $20.7 \%$ for placebo ( $P=0.033,0.072,0.201,0.294$ vs. placebo) over weeks $1-12$ (Dodick et al., 2019). ALD403 is currently in phase III development for the preventive treatment of migraine for patients with episodic and chronic migraine (https://clinicaltrials.gov/ct2/ show/study/NCT02559895; https://clinicaltrials.gov/ct2/show/ NCT02974153). The studies summarized here report the characterization of the in vitro and in vivo pharmacologic properties of the CGRP ligand-directed inhibitor antibody, ALD403.

\section{Materials and Methods}

Generation, Humanization, and Engineering of ALD403. Antibodies against human $\alpha$-CGRP (unless otherwise indicated, "CGRP" refers to $\alpha$-CGRP) were generated in New Zealand White rabbits immunized with human CGRP (National Center for Biotechnology Information NP_001029125.1; American Peptides, Sunnyvale, CA, and Bachem, Torrance, CA). Candidate antibodies were initially identified in conditioned B-cell culture supernatants as capable of binding biotinylated CGRP by ELISA using conditioned B-cell culture supernatants as previously described (Lightwood et al.,
2006). CGRP-binding antibodies were further characterized for their ability to inhibit CGRP-driven intracellular cAMP accumulation in SK-N-MC cells (Van Valen et al., 1990). ALD403 variable regions were cloned onto a human full-length IgG framework and subsequently humanized and engineered to minimize interactions with the immune system. Humanization was performed by grafting the complementarity-determining regions (CDRs) into the closest human variable $(\mathrm{V})$ region light- and heavy-chain framework sequences (V1-27 and V3-66, respectively) as previously described (Jones et al., 1986; Almagro and Fransson, 2008). Inhibition of CGRP-induced cAMP accumulation was used to monitor potency of the humanized variants. To maximize the potency of the humanized sequences of ALD403, a total of 13 amino acids between the light- and heavy-chain human framework sequences were reverted to the rabbit sequence. Canonical asparagine 297 in the heavy chain was specifically mutated to alanine (N297 mutation) to avoid $\mathrm{Fc} \gamma \mathrm{R}$ and complement protein interactions.

Inhibition of CGRP Signaling. To monitor the potency of antibodies, inhibition of CGRP-driven cAMP accumulation was measured using electrochemiluminescence assays [Meso Scale Discovery (MSD)]. Briefly, antibody preparations to be tested were serially diluted in MSD assay buffer, and human CGRP was added (2.6 nM final concentration unless otherwise indicated). This mix was incubated for 1 hour at $37^{\circ} \mathrm{C}$. Human neuroepithelioma cells [SK-N-MC, American Type Culture Collection (ATCC), Manassas, VA, cat. no. HTB-10] were detached using an EDTA solution (5 mM in PBS) and washed using growth media (minimal essential medium, 10\% FBS, antibiotics) by centrifugation. The cell number was adjusted to 2 million cells per milliliter in assay buffer, and 3-isobutyl-1-methylxanthine (Sigma Aldrich, St. Louis, MO) was added to a final concentration of $0.2 \mathrm{mM}$. Twenty microliters of the premixed antibody and CGRP were added to the assay plate (MSD); $10 \mu \mathrm{l}$ of cells were added to this mixture and incubated for 30 minutes with shaking at room temperature. The cells were then lysed using $20 \mu \mathrm{l}$ of lysis buffer containing TAG cAMP (MSD) and incubated for 1 hour while shaken at room temperature. Prior to reading the plate, $100 \mu l$ of $1.5 \times$ concentrated read buffer (MSD) was added to all wells on the plate and the plate was read using a Sector Imager 2400 (MSD). GraphPad Prism software (version 8.0) was used for data fit and $\mathrm{IC}_{50}$ determination.

Inhibition of CGRP Binding to Human CGRP and AMY1 Receptors. ALD403 preparations were serially diluted in assay buffer [50 nM Hepes-NaOH (pH 7.4), $10 \mathrm{mM} \mathrm{MgCl}_{2}, 4 \mathrm{mM} \mathrm{KCl}$, $10 \mathrm{mM} \mathrm{NaCl}, 1 \mathrm{mM}$ EDTA, $1 \mu \mathrm{M}$ phosphoramidon, $0.3 \%$ bovine serum albumin (BSA), and 0.04 bacitracin] to a final antibody concentration ranging from $20 \mathrm{nM}$ to $2 \mathrm{pM}$ and incubated with $\left[{ }^{125} \mathrm{I}\right]-\alpha$-CGRP $(0.03$ $\mathrm{nM}$ for CGRP receptor and $0.2 \mathrm{nM}$ for AMY1 receptor; Chelatec, France) for 15 minutes at $22^{\circ} \mathrm{C}$. This mixture was then incubated with cell membrane homogenates expressing either the CGRP receptor or the AMY1 receptor (containing 16 or $10 \mu \mathrm{g}$ of protein, respectively; ChemiScreen; EMD Millipore) and incubated for 90 minutes (CGRP receptor) or 120 minutes (AMY1 receptor) at $22^{\circ} \mathrm{C}$. Following this incubation, the samples were filtered under vacuum through glass fiber filters (GF/B; Packard) presoaked with $0.3 \%$ polyethylenimine and rinsed several times with ice-cold rinse buffer $(50 \mathrm{mM}$ Tris- $\mathrm{HCl}$, $150 \mathrm{mM} \mathrm{NaCl}$ ). The filters were dried and counted for radioactivity in a scintillation counter (TopCount; Packard) using a scintillation cocktail (Microscient 0; Packard).

The specific binding signal was determined by subtracting nonspecific binding $\left(\left[{ }^{125} \mathrm{I}\right]-\alpha\right.$-CGRP in the presence of $1 \mu \mathrm{M}$ unlabeled $\alpha$-CGRP) from total binding. The standard reference compound was unlabeled $\alpha$-CGRP, which was tested in each experiment at a range of concentrations to establish a competition curve from which the $\mathrm{IC}_{50}$ was calculated.

Characterization of Antibody-Dependent Cell-Mediated Cytotoxicity, Antibody-Dependent Cell-Mediated Phagocytosis, and Complement-Dependent Cytotoxicity Activation by ALD403. To confirm the lack of Fc-mediated antibody-dependent cell-mediated cytotoxicity (ADCC) and antibody-dependent cellmediated phagocytosis (ADCP) by ALD403, the antibody was tested 
for the ability to activate Fc $\gamma$ RIIIa and Fc $\gamma$ RIIa, the primary mediators of ADCC and ADCP, respectively (Dorokhov et al., 2016). Reporter bioassays were used according to manufacturer's instructions (cat. nos. G7010 and G9991; Promega Corporation). Briefly, the day before the assay, SK-N-MC cells were harvested using $5 \mathrm{mM}$ EDTA and resuspended in growth media [EMEM (Eagle's Minimum Essential Medium) and L-glutamine (cat. no. 30-2003; ATCC), GlutaMAX (cat. no. 35050-061; Gibco), and heat-inactivated FBS (cat. no. F8067; Sigma Aldrich)]. SK-N-MC cells (100 $\mu$ l per well, $3 \times$ $10^{5}$ per ml) were plated into 96-well CELLSTAR plates (cat. no. 655083; Greiner Bio-One) and incubated overnight at $37^{\circ} \mathrm{C}$. ALD403 preparations were serially diluted in assay buffer (RPMI 1640, 4\% low IgG serum; Promega Corporation) for a final assay concentration ranging from $6.1 \mathrm{pM}$ to $40 \mathrm{nM}$. SK-N-MC cells were washed with assay buffer, after which ALD403 was added to each well. For the assay conditions containing CGRP, a final concentration of $10 \mathrm{nM}$ was added. This amount of CGRP was chosen based on results of separate signaling assays where $10 \mathrm{nM}$ CGRP was found to be in excess of the amount needed for maximum cellular response. CGRP-free assay conditions received an equivalent volume of assay buffer. As a positive control, an anti-CD20 antibody and $1.5 \times 10^{4}$ Raji cells (cat. no. CCL86; ATCC) expressing CD20 were used. Cells were plated, and antiCD20 IgG1 antibody (cat. no. hcd20-mab1; Invivogen) was serially diluted as described for ALD403 and added to the appropriate wells. After 15 minutes preincubation, $25 \mu \mathrm{l}$ of Jurkat effector cells expressing the appropriate Fc $\gamma$ receptor with an NFAT (Nuclear Factor of Activated T-Cells)-luciferase reporter gene were diluted in assay buffer per the provider's protocol and were added to each well and incubated for 6 hours at $37^{\circ} \mathrm{C}$. Plates were removed from the incubator and placed in ambient temperature for 15 minutes, and $75 \mu \mathrm{l}$ of BioGlo reagent (Promega Corporation) was added to each well and further incubated at room temperature for 15 minutes protected from light. Luminescence was detected using a BioTek Synergy Neo and results were graphed using GraphPad Prism software (version 8.0).

To corroborate the lack of ALD403-driven complement-dependent cytotoxicity (CDC), SK-N-MC cells expressing the CGRP receptor were treated with human serum (cat. no. 35-060-CI; Corning) in the presence of ALD403 with or without CGRP. Briefly, the day before the assay, SK-N-MC cells were harvested using $5 \mathrm{mM}$ EDTA and resuspended in growth media. Aliquots of $100 \mu \mathrm{l}$ per well of SK-NMC $\left(1 \times 10^{5} /\right.$ well $)$ were plated into clear-bottom 96 -well black tissue culture plates (cat. no. 3603; Corning). As a positive control, an antiCD20 antibody and Ramos.2G6.4C10 (Ramos) cells (cat. no. CRL1923; ATCC) expressing CD20 were used. On the day of the assay, media was aspirated and rinsed with serum-free SK-N-MC growth media. Ramos cells were pelleted, washed, and resuspended in serumfree Ramos growth media [RPMI-1640 (cat. no. 30-2001; ATCC), GlutaMAX]. Ramos cells $\left(100 \mu \mathrm{l}, 1 \times 10^{5} /\right.$ well $)$ were plated into a V-bottom 96-well plate (cat. no. 3894; Corning) and pelleted, and the supernatant was removed. ALD403 and anti-CD20 IgG1 antibodies were serially diluted in cell-specific media supplemented with $20 \%$ human serum with or without CGRP (10 nM final concentration) and added to cells. Control wells received heat-inactivated human serum. Final antibody concentrations ranged from $93.3 \mathrm{pM}$ to $66.7 \mathrm{nM}$ (final volume of $100 \mu \mathrm{l}$ ). Samples were incubated at $37^{\circ} \mathrm{C}$ for 2 hours, after which the supernatants were aspirated (SK-N-MC cells) or pelleted and aspirated (Ramos cells), and the cells washed with $200 \mu \mathrm{l}$ Dubelcco's Phosphate Buffered Saline (DPBS). Cells were resuspended in $150 \mu \mathrm{l}$ per well of DPBS containing $100 \mathrm{nM}$ Calcein AM (cat. no. C3099; Invitrogen) and further incubated for 30 minutes. Ramos cells were then pelleted and washed using DPBS, and SK-NMC cells were harvested using $25 \mu$ l of Trypsin (cat. no. SH30042.01; HyClone) followed by the addition of $125 \mu \mathrm{l}$ of growth media to inactivate the trypsin. Cells were then pelleted and washed in DPBS followed by a final resuspension in $150 \mu$ l of DPBS. Cell viability was assessed by Calcein AM uptake as determined by flow cytometry (Accuri C6; BD), and results were analyzed using GraphPad Prism software (version 8.0).

\section{VL Humanization}

Rabbit 403VL Human V1-27 Humanized

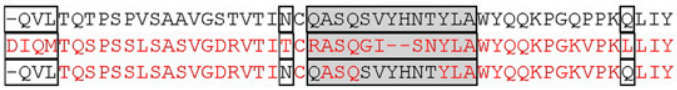

Rabbit 403VL Human V1-27 Humanized

Rabbit 403VL Human FR4

Humanized

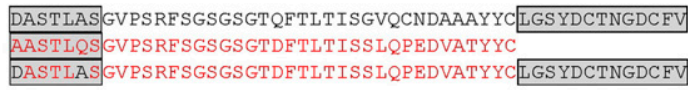
FGGGTEVVVK FGGGTEVVK PGGTKR:

\section{VH Humanization}

Rabbit 403VH Human V3-66 Humanized

Rabbit 403VH Human V3-66 Humanized

Rabbit 403VH Human FR4 Humanized

Fig. 1. Humanization of ALD403 variable region. The original rabbitvariable light-chain and variable heavy-chain amino acid sequences ("Rabbit 403VL" and "Rabbit 403VH") are aligned with the obtained homologous human variable light-chain and variable heavy-chain amino acid sequences ("Human V1-27" and "Human V3-66," respectively). The final humanized sequences are shown; red amino acids are identical to the human sequences, and black amino acids are different than the human sequences and were derived from the original rabbit antibody sequences.

ALD403 Interactions with Fc $\gamma$ Receptors. The interaction of ALD403 with human Fcy (RI, RIIA, RIIB/C, RIIIA, and RIIIB) receptors was assessed using surface plasmon resonance. A GLC primary amine-coupling sensor (cat. no. 176-2240; Bio-Rad, Hercules, CA) was hydrated and preconditioned using $0.5 \%$ SDS, $50 \mathrm{mM} \mathrm{NaOH}$, and $100 \mathrm{mM} \mathrm{HCl}$ per manufacturer protocol. The sensor surface was activated by injecting a mixture of 50\% 1-ethyl-3-(3-dimethylaminopropyl) carbodiimide hydrochloride (EDC)/50\% N-hydroxysuccinimide (NHS) solution at final $1 \times$ concentration (Bio-Rad), with a $30 \mu \mathrm{l} / \mathrm{min}$ for 300 seconds' flow. Prior to immobilization, the Fc $\gamma$ receptors [Fc $\gamma$ RI/CD64, cat. no. 1257-FC-050; Fc $\gamma$ RIIA/CD32a, cat. no. 1330CD-050; Fc $\gamma$ RIIB/C (CD32b/c), cat. no. 1875-CD-050; Fc $\gamma$ RIIIA/ CD16a, cat. no. 4325-FC-050; Fc $\gamma$ RIIIB/CD16b, cat. no. 1597-fc-050/ CF; R\&D Systems, Minneapolis, MN] were diluted to $7 \mu \mathrm{g} / \mathrm{ml}$ in $20 \mathrm{mM}$ sodium acetate $\mathrm{pH} 5.5$ and coupled to the EDC/NHS-activated GLC sensor prior to ethanolamine (0.33 M; Bio-Rad) deactivation per default settings. Prior to test article injection, running buffer was allowed to equilibrate to achieve a stable baseline signal. To determine the association rate of test articles onto immobilized $\mathrm{Fc} \gamma \mathrm{R}$ surface, five 3 -fold serial dilutions of antibodies were made from 10,000 $\mathrm{nM}$ down to $123 \mathrm{nM}$ in running buffer [PBS containing $1 \%$ Tween-20 (cat. no. P1192; Teknova)]. The antibody dilutions were allowed to interact with the Fc $\gamma \mathrm{R}$ using a $100 \mu \mathrm{l} / \mathrm{min}$ flow rate for a 30 -second injection followed by a 90 -second dissociation phase using running buffer. Experiments for multiple test articles and the positive control were performed in sequence and bracketed by 1000 -second blank injections. Data were referenced against interspots and fit using a 1:1 Langmuir model (ProteOn Manager Software, version 3.1.0.6; Bio-Rad) with $\mathrm{k}_{\mathrm{a}}$ and $\mathrm{k}_{\mathrm{d}}$ grouped by test article and $\mathrm{R}_{\max }$ and $\chi^{2}$ reported as averages for each test article. Subsequently, $K_{\mathrm{D}}$ was calculated from the $k_{\mathrm{d}} / k_{\mathrm{a}}$ values. Samples with $<10$ response units (RUs) of signal above blank injection or $<5 \%$ of positive control visual $R_{\max }$ were assigned "no measurable binding."

Binding Kinetics and Specificity of ALD403. Surface plasmon resonance was used to characterize the binding of ALD403 to human and rat CGRP peptides using the ProteOn XPR36 instrument (Bio-Rad). For analysis of human CGRP peptides, ProteOn Neutravidin sensors (cat. no. 176-5021; Bio-Rad) were hydrated and conditioned using $1 \mathrm{M}$ $\mathrm{NaCl}$ and $50 \mathrm{mM} \mathrm{NaOH}$ per the manufacturer's protocol. ALD403 was 
A

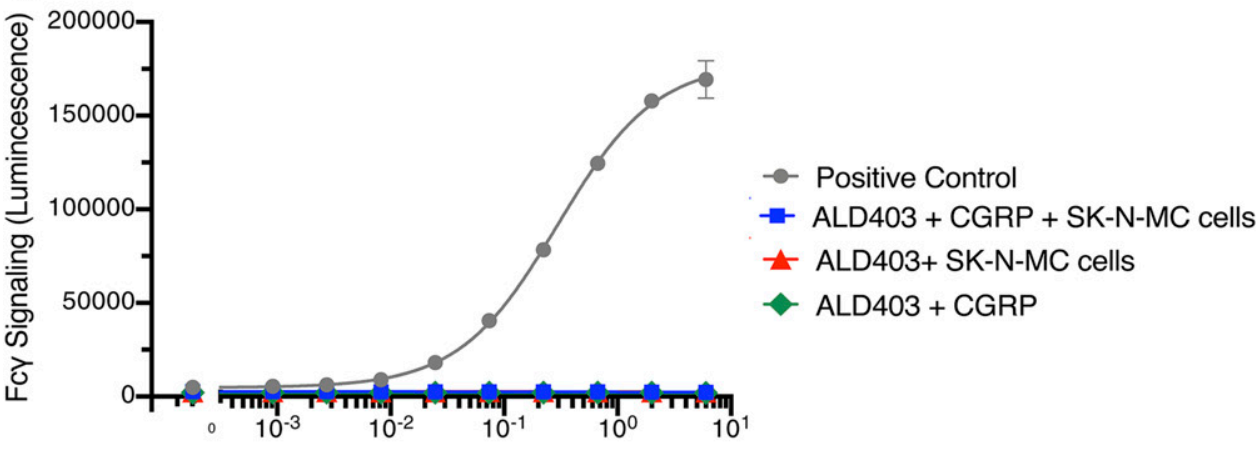

Antibody $(\mu \mathrm{g} / \mathrm{mL})$

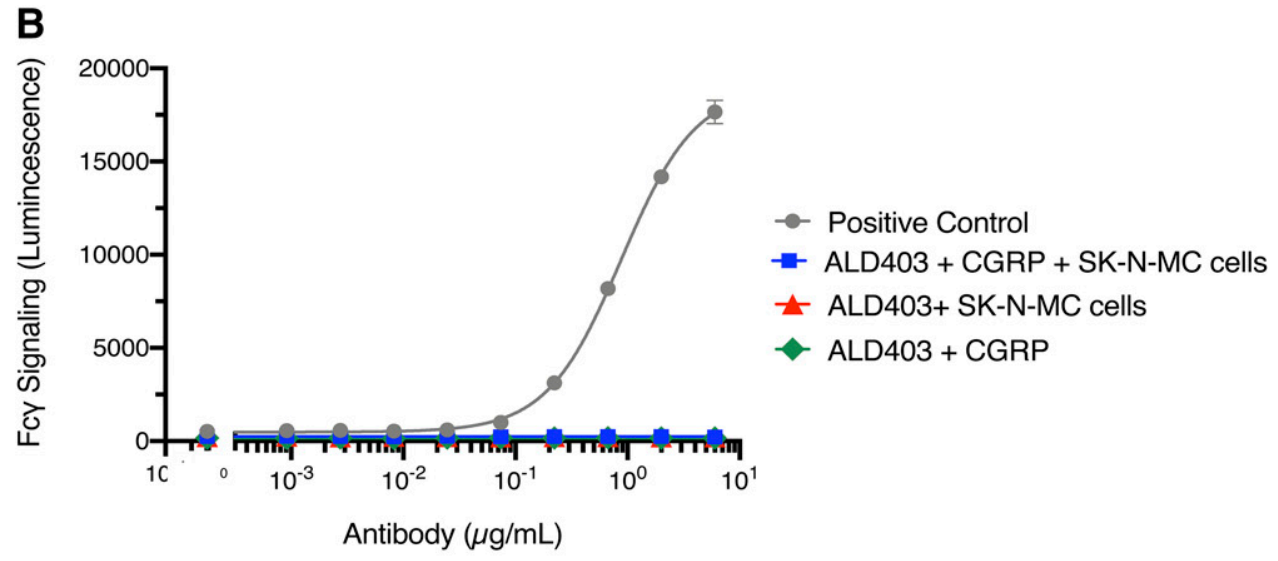

Fig. 2. Lack of $A D C C(A)$, and $A D C P(B)$ activation, and $\mathrm{CDC}(\mathrm{C})$ stimulation by ALD403. ADCC, ADCP, and CDC activation by ALD403 were analyzed in vitro, and results were graphed compared with a positive control antibody. ADCC and ADCP activities were determined by activation of the relevant $\mathrm{Fc} \gamma$ receptors (Fc $\gamma$ RIII and Fc $\gamma$ RII, respectively) in reporter cell lines. Results show averages \pm S.D. of triplicate samples. CDC was measured by ability of target cells to absorb a fluorescent vital dye in the presence of antibody and active complement components. Results are single samples in an assay representative of three independent analyses.

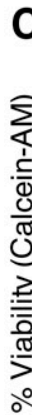

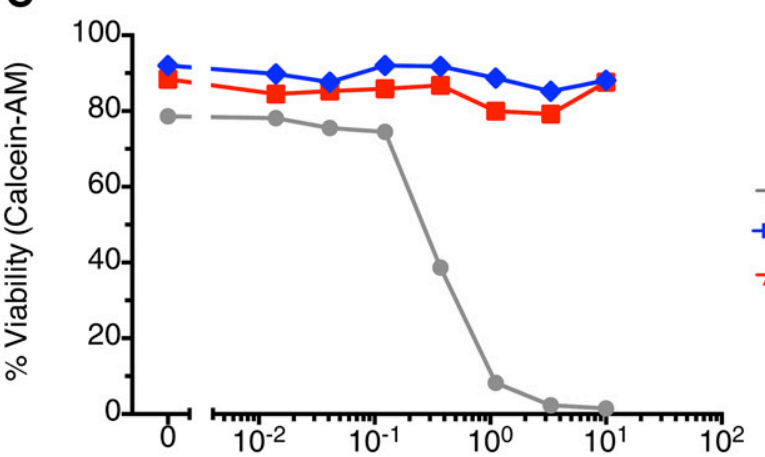

- Positive Control

- ALD403 + CGRP + SK-N-MC cells

— ALD403+ SK-N-MC cells

Antibody $(\mu \mathrm{g} / \mathrm{mL})$

biotinylated [1:20 molar ratio of antibody: Sulfo-NHS-LC-LC-Biotin (cat. no. 21338; Thermo Fisher Scientific, Waltham, MA)] and exchanged to DPBS using a $0.5 \mathrm{ml} 7 \mathrm{k}$ MWCO Zeba Spin Column (cat. no. 89882; Thermo). Biotinylated ALD403 was diluted in running buffer $(1 \times$ HBS-EP, $0.2 \mathrm{M}$ arginine, $0.2 \mathrm{mg} / \mathrm{ml} \mathrm{BSA}$, and $0.005 \% \mathrm{Na}$ azide) to a final concentration of $3-5 \mu \mathrm{g} / \mathrm{ml}$ and allowed to interact with the biosensor (300 second at $30 \mu \mathrm{l} / \mathrm{min}$ ) until an average surface density of 1000-2300 RUs were reached. For analysis of rat CGRP peptides, the composition of the running buffer used was $(1 \times \mathrm{HBS}$ $\mathrm{EP}^{+}$(Hepes-buffered saline- EDTA Polysorbate $)+0.2 \mathrm{mg} / \mathrm{ml} \mathrm{BSA} \mathrm{+}$ $0.005 \% \mathrm{Na}$ azide). Medium density amine reactive sensors (GLM Sensor Chip, cat. no. 176-5012; Bio-Rad) were hydrated and conditioned using $0.5 \%$ SDS solution, $50 \mathrm{mM} \mathrm{NaOH}$, and $100 \mathrm{mM} \mathrm{HCl}$, and each sensor was activated using a mixture of $\operatorname{EDC}(1 \times)$ and NHS $(1 \times)$ according to manufacturer recommendations. ALD403 antibody preparation was diluted to 15 and $2 \mu \mathrm{g} / \mathrm{ml}$ using a $10 \mathrm{mM}$ sodium acetate $\mathrm{pH} 5.0$ buffer and allowed to couple onto the EDC/NHS-activated GLM sensor using a $30 \mu \mathrm{l} / \mathrm{min}$ flow rate for a total of 300 seconds. Ethanolamine $(1 \mathrm{M})$ was then used for quenching according to manufacturer's recommendations. This resulted in surface densities of ALD403 of 7000-10,000 RUs and 2000-3000 RUs, respectively, after coupling to the activated sensor.

To determine $k_{\mathrm{a}}$ and $k_{\mathrm{d}}$ and to calculate the $K_{\mathrm{D}}$ of the CGRP peptide analytes, five 3 -fold serial dilutions of the different CGRP peptides [human $\alpha$-CGRP (cat. no. 22-1-12; American Peptides); human $\alpha$-CGRP (cat. no. 1057151; Bachem)] were made with a starting concentration of $100 \mathrm{nM}$ and the lowest concentration being $1.2 \mathrm{nM}$ in running buffer. Dissociation constant experiments for both forms of CGRP were performed using the highest analyte concentration and dissociation times of $80,000-86,000$ seconds.

To establish the specificity of ALD403 for CGRP compared with closely related peptides, a similar method to that described above to determine the binding kinetics was used with the following modifications. ALD403 was immobilized via amine coupling using a ProteOn GLC Chip (cat. no. 176-5011; Bio-Rad) per manufacturer's 
FcyRIIIA

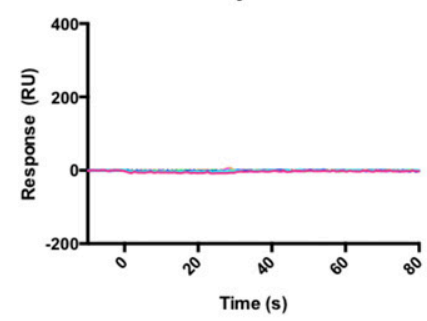

FcyRIIIB

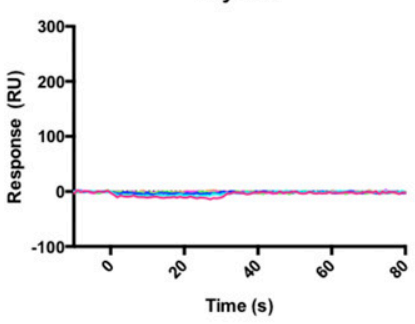

FcyRIIA

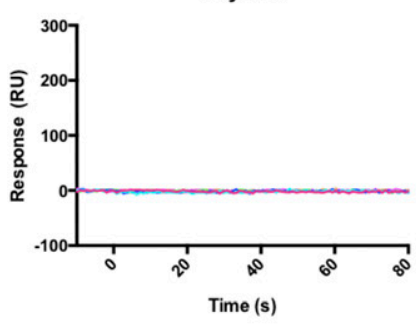

FcyRIIB/C

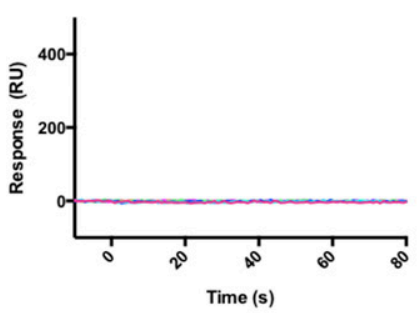

FcyRI

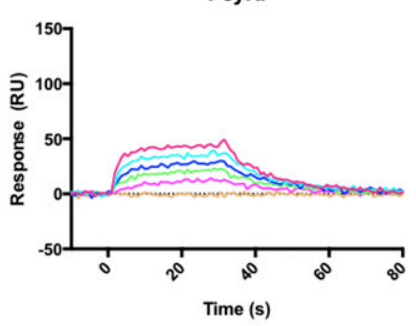

- ALD403 - 10uM

- ALD403 - 3.3uM

- ALD403 - 1.1uM

- ALD403 - 370nM

- ALD403 - 123nM

- Buffer
FcyRIIIA_+ctrI

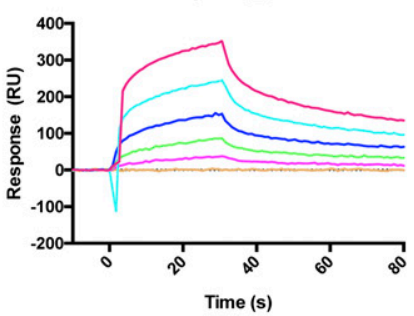

FcyRIIIB_+ctrl

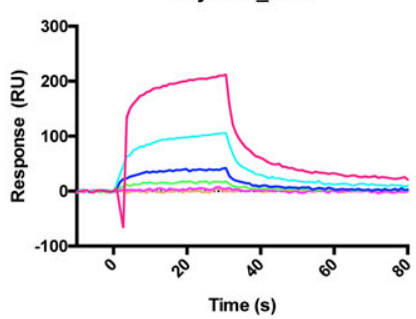

FcyRIIA_tctrl

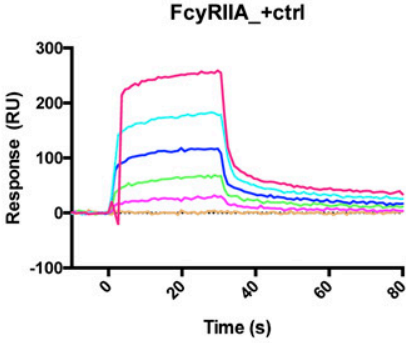

FcyRIIB/C_+ctrl

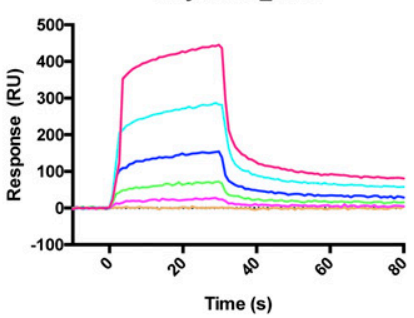

FcyRI_+ctrl

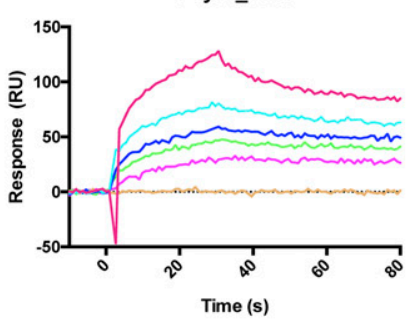

- Wild-type IgG1 - 10uM

- Wild-type IgG1 - 3.3uM

- Wild-type IgG1 - 1.1uM

- Wild-type IgG1 - 370nM

- Wild-type IgG1 - 123nM

- Buffer
Fig. 3. Characterization of ALD403 interactions with Fc $\gamma$ receptors (left column). ALD403 displays limited binding to Fc $\gamma$ RI and does not interact with RIIA, RIIB/C, RIIIA, and RIIIB immobilized via amine coupling onto a GLC Biosensor (ProteOn XPR36). Antibody concentrations used $10 \mu \mathrm{M}$ (red), $3.3 \mu \mathrm{M}$ (light blue), $1.1 \mu \mathrm{M}$ (dark blue), $0.37 \mu \mathrm{M}$ (green), $0.12 \mu \mathrm{M}$ (magenta), and buffer (orange). Data are referenced to interspots and buffer blank. Also shown (right column) binding by positive control whole human IgG1. 
recommendations, targeting average immobilization of 2000-5000 RUs. As control, $30 \mathrm{nM}$ CGRP was allowed to interact with immobilized ALD403 using a $100 \mu \mathrm{l} / \mathrm{min}$ flow rate for 90 seconds. Buffer used was $1 \times$ HBS-EP $^{+}$(Teknova), $0.2 \mathrm{M}$ arginine, $0.2 \mathrm{mg} / \mathrm{ml} \mathrm{BSA}$, and $0.005 \% \mathrm{Na}$ azide. In addition to CGRP, the following peptides were tested using a 25-fold higher concentration than that used for CGRP (1000 nM): amylin (cat. no. AS-60254-1; AnaSpec, Fremont, CA) and rat amylin (cat. no. AS-60253-1), calcitonin (cat. no. AS-20673), intermedin (cat. no. 65334-05), and adrenomedullin (cat. no. AS-60447).

Inhibition of Capsaicin-Driven Blood Flow in Rodents. The day prior to testing, male Sprague-Dawley rats (Harlan) were randomly assigned the following groups for dosing: group 1 received $30 \mathrm{mg} / \mathrm{kg}$ of a nonspecific control antibody, and groups 2-6 received ALD403 at $30,10,3,1$, or $0.3 \mathrm{mg} / \mathrm{kg}$, respectively. Antibodies were diluted in phosphate-buffered saline and administered intraperitoneally. An area approximately $2 \times 6 \mathrm{~cm}$ on the dorsal lower back was shaved and depilated for Doppler imaging.

On the day of the test, rats were anesthetized with isoflurane gas and placed on a temperature-controlled heating pad and fitted with a nose cone to provide continuous isoflurane delivery. A Moor LDI2 IR Laser Doppler imaging system (Moor Instruments, UK) was used to monitor vasodilation. A baseline Doppler scan was conducted to identify areas of low blood flow for placement of two rubber O-rings $(<1 \mathrm{~cm}$ in diameter). After O-ring placement, a baseline Doppler scan was performed. Immediately after completion of the scan, $1 \mathrm{mg}$ capsaicin (cat. no. M2028; Sigma Aldrich) in $5 \mu$ l 1:1 ethanol:acetone was applied to the skin within each O-ring. Doppler scans were repeated at 2.5, 5, 7.5, 10, $12.5,15,17.5,20,22.5,25,27.5$, and 30 minutes after capsaicin application. Percent change from baseline mean flux within each of the two O-rings was plotted as the results of vasodilation due to capsaicin. Means and S.D.s for each group, at each time, were calculated. GraphPad Prism software (version 8.0) was used for statistical analysis.

Toxicokinetic Parameters for ALD403 in Sprague-Dawley Rats Following a Single Intravenous Bolus Injection. The toxicokinetic (TK) characteristics of ALD403 were evaluated following a single intravenous injection to Sprague-Dawley rats at dose levels of 0, 10,30, or $100 \mathrm{mg} / \mathrm{kg} \mathrm{ALD} 403$ and 14 days' observation. A total of 12 rats (six male and six female) were dosed. Blood samples were collected prior to dosing, at 1 minute, and at 24, 96, 168, and 336 hours postdosing. The blood samples were processed for plasma and analyzed for ALD403 concentration by Charles River Laboratories, Reno, NV, using a validated indirect electrochemiluminescence (ECL) method. Plasma samples, standards, and quality control samples containing ALD403 at various concentrations were added to goat antihuman IgG-coated microtiter plates, 96-well format, and incubated for $60 \pm 5$ minutes at room temperature. After washing, a detection antibody (Biotinylated Human IgG) was added and incubated for an additional $60 \pm 5$ minutes at room temperature. The plates were washed again, $1 \times$ MSD Read Buffer was added to the wells, and an MSD Sector imager was used to evaluate light intensity, yielding quantitative measures (ECL signals) for ALD403 present in the samples. The ECL measurements were transferred to SoftMax Pro GxP, where the ALD403 concentrations were calculated using a fourparameter standard calibration curve.

The TK parameters were estimated using WinNonlin pharmacokinetic software (Pharsight Corp., Mountain View, CA). A noncompartmental approach consistent with the intravenous route of administration was used for parameter estimation. All parameters were generated from mean ALD403 concentrations in plasma from day 1 to 14 using sampling times relative to the start of dose administration.

\section{Results}

Identification of ALD403. A panel of anti-CGRP antibodies was generated by single B-cell antibody cloning from rabbits that had been immunized with human CGRP. The candidate anti-CGRP antibodies were identified by their
TABLE 1

Affinity of ALD403 for Fc $\gamma$ receptors

\begin{tabular}{|c|c|c|c|c|}
\hline Receptor & Antibody & $\mathrm{k}_{\mathrm{a}}$ & $\mathrm{k}_{\mathrm{d}}$ & $\mathrm{K}_{\mathrm{D}}$ \\
\hline & & $\mathrm{M}^{-1} \mathrm{~s}^{-1}$ & $\mathrm{~s}^{-1}$ & M \\
\hline \multirow[t]{2}{*}{$\mathrm{Fc} \gamma \mathrm{RI}$} & ALD403 & $8.19 \mathrm{E}+04$ & $5.95 \mathrm{E}-02$ & $7.26 \mathrm{E}-07$ \\
\hline & Human IgG & $1.17 \mathrm{E}+05$ & $2.03 \mathrm{E}-03$ & $1.74 \mathrm{E}-08$ \\
\hline \multirow[t]{2}{*}{ Fc $\gamma$ RIIA } & ALD403 & NMB & NMB & NMB \\
\hline & Human IgG & $2.38 \mathrm{E}+05$ & $4.46 \mathrm{E}-01$ & $1.87 \mathrm{E}-06$ \\
\hline \multirow[t]{2}{*}{$\mathrm{Fc} \gamma \mathrm{RIIB} / \mathrm{C}$} & ALD403 & NMB & NMB & NMB \\
\hline & Human IgG & $1.36 \mathrm{E}+05$ & $5.30 \mathrm{E}-01$ & $3.88 \mathrm{E}-06$ \\
\hline \multirow[t]{2}{*}{ Fc $\gamma$ RIIIA } & ALD403 & NMB & NMB & NMB \\
\hline & Human IgG & $5.29 \mathrm{E}+04$ & $8.79 \mathrm{E}-02$ & $1.66 \mathrm{E}-06$ \\
\hline \multirow[t]{2}{*}{ Fc $\gamma$ RIIIB } & ALD403 & NMB & NMB & NMB \\
\hline & Human IgG & $7.46 \mathrm{E}+04$ & $5.10 \mathrm{E}-01$ & $6.84 \mathrm{E}-06$ \\
\hline
\end{tabular}

NMB, no measurable binding.

ability to bind to CGRP and by their ability to inhibit CGRPdriven intracellular cAMP accumulation in SK-N-MC cells (data not shown). These recombinant antibodies were initially chimeric, with the variable domains from rabbits and the constant heavy- and light-chain domains from human IgG1 and human kappa, respectively. ALD403 was humanized by CDR grafting into compatible human immunoglobulin germline variable genes (see Materials and Methods). Several additional non-CDR rabbit residues in the framework regions of the variable domains were determined to be necessary to retain desired binding and functional characteristics in the final humanized antibody. Figure 1 shows the original rabbit variable sequences of ALD403 along with the human germline genes used and the final humanized variable sequences of ALD403. Humanized ALD403 retained the capacity to inhibit CGRP-induced cAMP production; the chimeric antibody exhibited an $\mathrm{IC}_{50}$ of $434 \mathrm{pM}$ compared with an $\mathrm{IC}_{50}$ of 288 pM for the humanized ALD403 (see Supplemental Figs. 1 and 2).

ALD403 Does Not Support ADCC, ADCP, CDC, or Stable Fc $\gamma$ Receptor Interactions. Activation of cellmediated and/or complement-mediated immune processes by IgG antibodies heavily depend on the N-linked glycan at amino acid N297 of the Fc domain within the IgG molecule (Dorokhov et al., 2016; Saxena and Wu, 2016; Mimura et al., 2018). The amino acid N297 of ALD403 was mutated to alanine to prevent $\mathrm{N}$-linked glycosylation and, as expected, no N-linked glycosylation or N-linked carbohydrate was observed in ALD403 (data not shown).

As engineered, ALD403 did not activate Fc $\gamma$ RIIIa (primary ADCC receptor (Koene et al., 1997) or Fc $\gamma$ RIIa [primary ADCP receptor (Richards et al., 2008)] alone or in the presence of CGRP or CGRP plus SK-N-MC cells (Fig. 2A). The positive control demonstrated robust signaling through both receptors. To monitor for complement-mediated immune functions,

TABLE 2

Binding constants of ALD403 to different CGRP molecules

\begin{tabular}{lccc}
\hline CGRP molecule & $k_{\mathrm{a}}$ & $k_{\mathrm{d}}$ & \multicolumn{1}{c}{$K_{\mathrm{D}}$} \\
\hline & $\mathrm{M}^{-1} \mathrm{~s}^{-1}$ & $\mathrm{~s}^{-1}$ & $\mathrm{M}$ \\
Human alpha & $2.6 \mathrm{E}+05$ & $1.0 \mathrm{E}-06$ & $4 \mathrm{E}-12$ \\
Human beta & $2.9 \mathrm{E}+05$ & $1.0 \mathrm{E}-06$ & $3 \mathrm{E}-12$ \\
Rat alpha & $3.9 \mathrm{E}+05$ & $6.4 \mathrm{E}-05$ & $1.7 \mathrm{E}-10$ \\
Rat beta & $5.8 \mathrm{E}+05$ & $5.1 \mathrm{E}-06$ & $8.4 \mathrm{E}-12$ \\
\hline
\end{tabular}

$\mathrm{k}_{\mathrm{a}}$, on-rates for binding affinity; $\mathrm{k}_{\mathrm{d}}$, off-rates for binding affinity; $K_{\mathrm{D}}$, binding affinity constant $\left(k_{\mathrm{d}} / k_{\mathrm{a}}\right)$. 


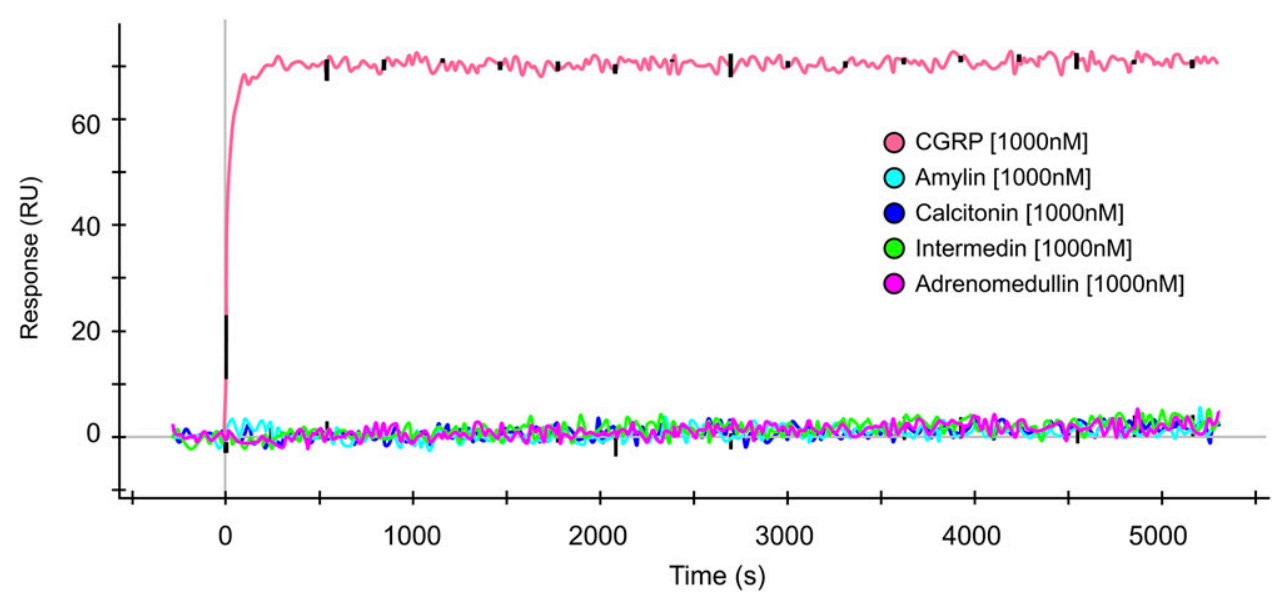

Fig. 4. Binding specificity of ALD403. Binding by $\alpha$-CGRP and noninteraction of superfamily of peptides (amylin, calcitonin, intermedin, adrenomedullin) to aminecoupled immobilized antibody (ALD403) on a GLC Biosensor (ProteOn XPR36). Peptides were allowed to interact with the immobilized ALD403 at a $1000 \mathrm{nM}$ concentration for 90 seconds. Data were referenced to interspots.
ALD403 was incubated with SK-N-MC cells in the presence of complement-containing human serum with or without CGRP. ALD403 did not support complement-mediated cell lysis (Fig. 2B). The positive control exhibited significant levels of cytotoxicity. Collectively, these data support that the Fc engineering performed in the construction of ALD403 successfully minimized/eliminated antibody effector functions.

To further confirm the profile of ALD403, in particular its interactions with the receptors that mediate the major immune processes mentioned above, the binding of ALD403 to the human Fc $\gamma$ receptors RI, RIIA, RIIB/C, RIIIA, and RIIIB was assessed by surface plasmon resonance and compared with a wild-type, glycosylated control IgG1 antibody. These receptors mediate immune functions such as ADCC, ADCP, maturation of dendritic cells, etc. ALD403 had no measurable binding to four of the five Fc $\gamma$ receptors and only weak binding to Fc $\gamma$ RI (Fig. 3; Table 1). The affinity $\left(\mathrm{K}_{\mathrm{D}}\right)$ of ALD403 for Fc $\gamma$ RI was reduced greater than 40-fold versus wild-type-nonmutated-IgG control (Table 1). This pattern of $\mathrm{Fc} \gamma$ receptor binding is consistent with presence of the N297A mutation in the heavy chain of ALD403 (Mimura et al., 2018).

Binding Kinetics and Specificity of ALD403. ALD403 binds with high affinity to both forms ( $\alpha$ and $\beta$ ) of human and rat CGRP with a fast on-rate and a slow off-rate (Table 2). CGRP sequences are most homologous with the peptides amylin, calcitonin, adrenomedullin, and intermedin (Wimalawansa, 1996), which have been proposed to be part of a superfamily of peptides (Wimalawansa, 1997). Surface plasmon resonance (ProteOn) was used to address the specificity of ALD403 binding to CGRP compared with the abovementioned peptides. ALD403 was immobilized via amine coupling onto a GLC ProteOn chip. Subsequently, each peptide was presented to the immobilized antibody, and their binding was monitored. As expected, CGRP was able to efficiently bind to and be retained by the immobilized ALD403. In contrast, none of the other peptides tested were able to stably interact with the immobilized antibody (Fig. 4).

ALD403 Inhibits Binding of CGRP to Both the CGRP and AMY1 Receptors. CGRP binds two receptors with high affinity: the CGRP receptor (which is composed of a complex of calcitonin-like receptor and receptor activity-modifying protein 1) and the AMY1 receptor (composed of calcitonin receptor and receptor activity-modifying protein 1) (Tilakaratne et al., 2000; Hay et al., 2006, 2018; Moore and Salvatore, 2012; Walker et al., 2015; Hay and Walker, 2017). The ability of ALD403 to inhibit binding of CGRP to the CGRP receptor and AMY1 receptor was evaluated in competitive binding experiments using cell-membrane preparations expressing each of these receptors. Preincubation of ALD403 with $\left[{ }^{125} \mathrm{I}\right]$-labeled $\alpha$-CGRP was able to inhibit CGRP binding in a dosedependent manner exhibiting an $\mathrm{IC}_{50}$ of $4.7 \times 10^{-11}$ and $1.2 \times 10^{-10} \mathrm{M}$ for the CGRP and AMY1 receptors, respectively
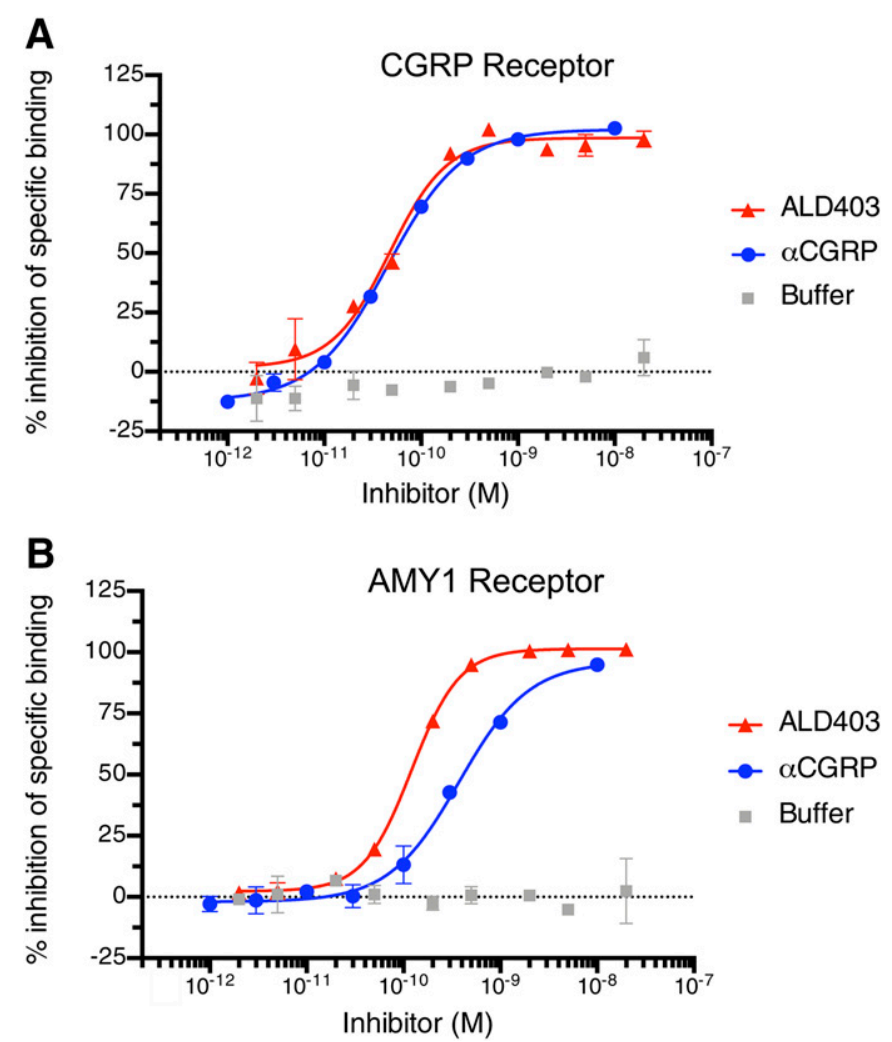

Fig. 5. Inhibition of CGRP binding to (A) CGRP receptor and (B) AMY1 receptor with ALD403. Displacement of $\left[{ }^{125} \mathrm{I}\right]-\mathrm{CGRP}$ binding to CGRP and AMY1 receptors by increasing amounts of ALD403 and unlabeled CGRP were measured, and $\mathrm{IC}_{50}$ values were obtained. GraphPad Prism software (version 8.0) was used to generate the fit curves and calculate $\mathrm{IC}_{50}$ values. Results show averages of duplicate samples. 


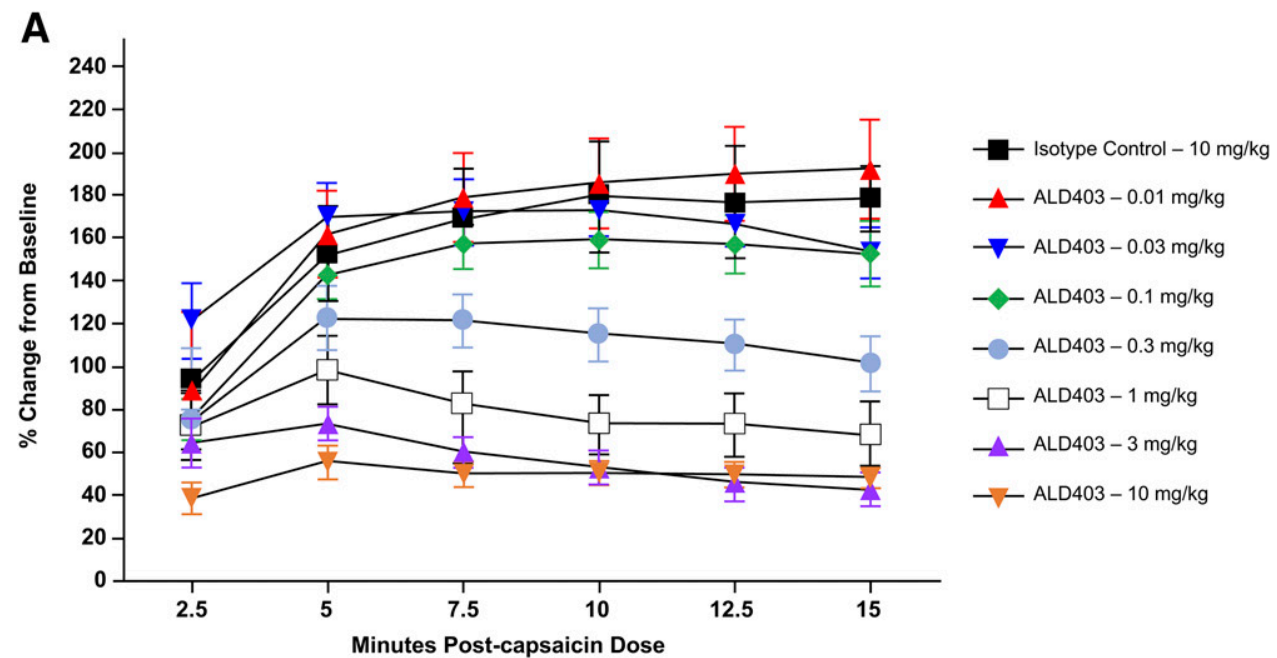

B

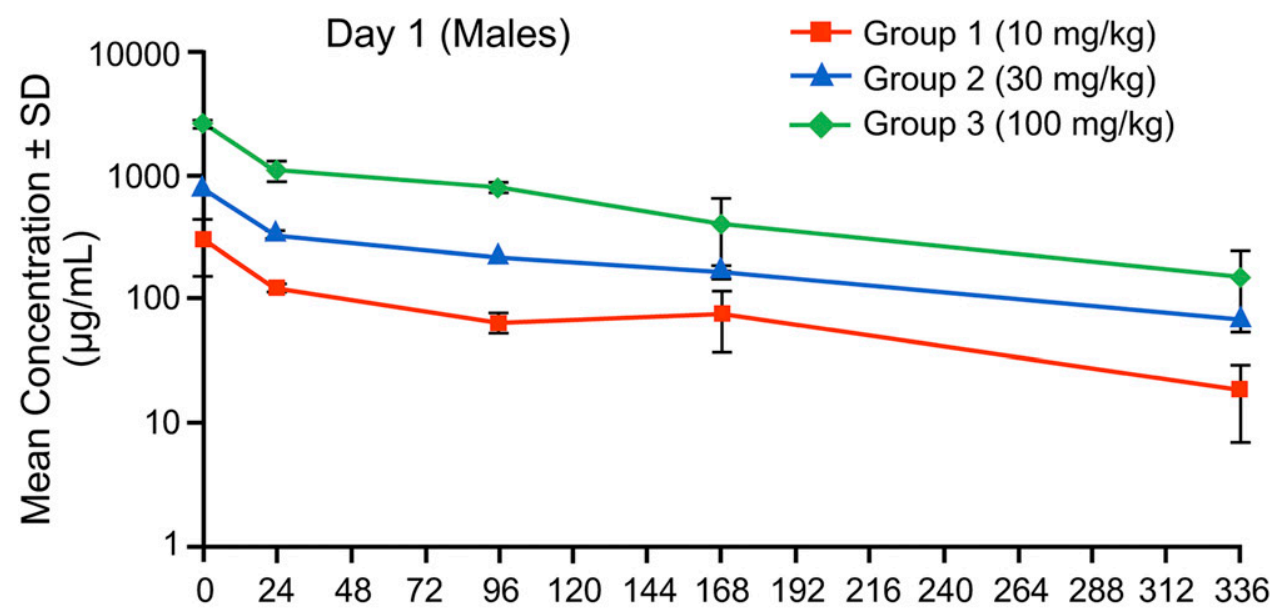

Fig. 6. Inhibition of capsaicin-driven increased blood flow (A) and mean plasma concentration-time profiles of ALD403 in rodents (B). Changes in dermal blood flow were measured using laser Doppler imaging following topical application of capsaicin solution. ALD403 at different dose levels or a nonspecific isotype control $\mathrm{Ab}$ (AD26-10) was injected intraperitoneally 24 hours prior to capsaicin challenge. Doppler scans were repeated every 2.5 minute for 15 minutes after application. The percent change from baseline was calculated from the mean flux values for each animal $(n=6)$. ALD403 plasma concentration levels were measured for all doses and shown in (B).

Nominal Time (h)

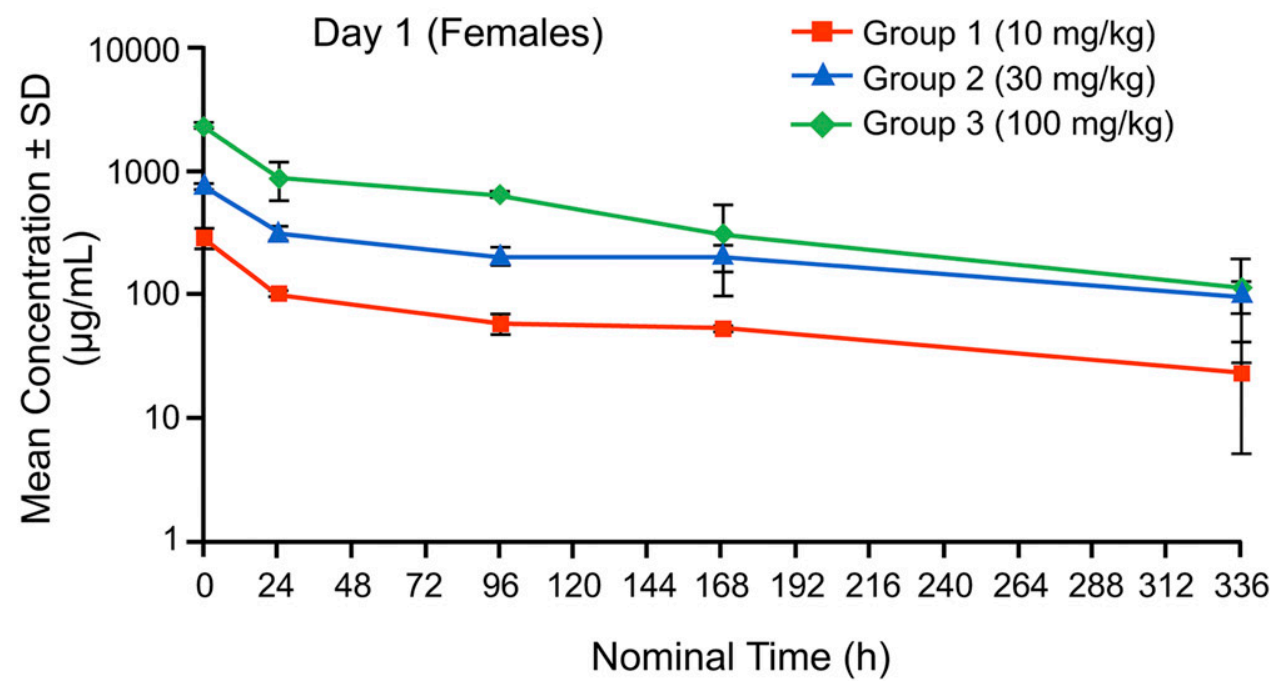


TABLE 3

Single-dose toxicokinetic parameters for ALD403 in rats

\begin{tabular}{lcccccccc}
\hline Dosage & $\mathrm{Sex}$ & $\mathrm{t}_{\max }$ & $\mathrm{C}_{\max }$ & $\mathrm{AUC}_{0-\text { tlast }}$ & $\mathrm{AUC}_{0-\text { inf }}$ & $\mathrm{t}_{1 / 2}$ & $\mathrm{CL}$ & $\mathrm{Vz}$ \\
\hline $\mathrm{mg} / \mathrm{kg}$ & & $\mathrm{h}$ & $\mu \mathrm{g} / \mathrm{ml}$ & $\mu \mathrm{g} \cdot \mathrm{h} / \mathrm{ml}$ & $\mu \mathrm{g} \cdot \mathrm{h} / \mathrm{ml}$ & $\mathrm{h}$ & $\mathrm{ml} / \mathrm{h} \cdot \mathrm{kg}$ & $\mathrm{ml} / \mathrm{kg}$ \\
10 & $\mathrm{M}$ & 0.017 & 302 & 24,998 & 28,205 & 120 & 0.355 & 61.5 \\
& $\mathrm{~F}$ & 0.017 & 301 & 21,102 & 26,351 & 155 & 0.380 & 84.8 \\
30 & $\mathrm{M}$ & 0.017 & 774 & 67,822 & 81,448 & 138 & 0.368 & 73.4 \\
& $\mathrm{~F}$ & 0.017 & 770 & 72,479 & $\mathrm{RNR}$ & $\mathrm{RNR}$ & $\mathrm{RNR}$ & $\mathrm{RNR}$ \\
100 & $\mathrm{M}$ & 0.017 & 2629 & 203,424 & 226,313 & 105 & 0.442 & 67.2 \\
& $\mathrm{~F}$ & 0.017 & 2313 & 164,289 & 180,871 & 102 & 0.553 & 81.4 \\
\hline
\end{tabular}

$\mathrm{AUC}_{0-\text { inf, }}$ area under the plasma concentration-time curve from time zero extrapolated to infinity; $\mathrm{AUC}_{0-\text { tlast }}$, area under the plasma concentration-time curve from time zero to the time of the last quantifiable ALD403 concentration; CL, total body clearance; $\mathrm{C}_{\max }$, maximum observed concentration; $\mathrm{F}$, female; $\mathrm{M}$, male; RNR, result not reported as the $\mathrm{AUC}_{0-\text { inf }}$ was extrapolated by more than $20 \%$ or the $R^{2}$ was $<0.800 ; \mathrm{t}_{1 / 2}$, terminal half-life; $\mathrm{T}_{\max }$, time at maximal concentration; $\mathrm{V}_{\mathrm{Z}}$, apparent volume of distribution during terminal elimination phase.

(Fig. 5). Unlabeled $\alpha$-CGRP was used as a positive control in these assays and displayed an $\mathrm{IC}_{50}$ of $4.5 \times 10^{-11}$ for the CGRP receptor and $3.7 \times 10^{-10} \mathrm{M}$ for the AMY1 receptor.

Inhibition of Capsaicin-Driven Increased Blood Flow and TK Parameters of ALD403. Dermal application of capsaicin produces a localized increase in blood flow that can be measured via laser Doppler imaging. Capsaicin activates the transient receptor potential vanilloid type 1 receptor, producing local release of vasoactive mediators, including CGRP, which results in localized dermal vasodilation (Hershey et al., 2005; Van der Schueren et al., 2007; Sinclair et al., 2010). The ability of ALD403 to inhibit this activity was evaluated in rats. Animals previously treated with an IgG control antibody responded to capsaicin treatment with elevations of blood flow starting at 2.5 minutes after capsaicin administration. The response plateaued at around 12.5 minutes and was sustained for at least 15 minutes. Administration of ALD403 24 hours prior to capsaicin treatment resulted in a dosedependent inhibition of capsaicin-driven blood flow relative to animals treated with the negative control antibody. Animals that had received $\geq 0.3 \mathrm{mg} / \mathrm{kg}$ doses of ALD403 exhibited significantly lower responses at $5,10,12.5$, and 15 minutes after capsaicin administration (Fig. 6A).

To characterize the TK parameters of ALD403 in rats, both male and female rats were dosed with increasing amounts of ALD403, and blood samples were collected prior to dosing and at 1 minute and at 24,96,168, and 336 hours postdosing for analysis of ALD403 in plasma. The mean plasma concentration-time profiles for ALD403 in rats were characterized by an apparent monoexponential decline (Fig. 6B). The TK parameters are summarized in Table 3 and revealed a half-life $\left(\mathrm{T}_{1 / 2}\right)$ of 124 hours.

\section{Discussion}

CGRP has been established as an important signal molecule in the pathophysiology of migraine, and inhibition of its function has demonstrated efficacy in the clinic for the treatment and prevention of migraines (Russo, 2015; Edvinsson, 2018a; Agostoni et al., 2019; Ceriani et al., 2019; Charles and Pozo-Rosich, 2019; Parikh and Silberstein, 2019; Tepper, 2019; Yuan et al., 2019). This report summarizes the discovery, engineering, and preclinical characterization of the humanized monoclonal antibody ALD403 targeting CGRP for the prevention of migraine. Advances in molecular engineering have facilitated the development of monoclonal antibodies with characteristics that maximize target interaction and minimize unwanted activities. Potential therapeutic antibodies are commonly humanized in an attempt to minimize the potential for an undesirable immune response (Kuramochi et al., 2019; Mayrhofer and Kunert, 2019; Waldmann, 2019). Humanization of ALD403 maintained its high affinity for both human and rat CGRP isoforms as well as its specificity for binding to CGRP over related peptides. The potency of inhibition in cell-based assays was also conserved after humanization. The Fc domain of ALD403 was successfully modified to minimize immune functions via either Fc $\gamma$ receptors or complement. ALD403 exhibits a very high affinity for both $\alpha$ and $\beta$ forms of human and rat CGRP, and its mechanism of action was demonstrated through the complete and potent blocking of [ $\left.{ }^{125} \mathrm{I}\right]-\mathrm{CGRP}$ binding to both of its primary receptors, the CGRP receptor and the AMY1 receptor. This inhibition of receptor binding results in the subsequent inhibition of CGRP-induced cAMP production in vitro and in vivo translates into inhibition of capsaicin-induced increases in dermal blood flow. These findings are consistent with clinical data demonstrating significant reduction in migraine headache days with favorable safety and tolerability (Dodick et al., 2014, 2019).

Scaffold glycoengineering such as that used to construct ALD403 (Tao and Morrison, 1989; Simmons et al., 2002) has allowed researchers to design antibodies that do not engage in unnecessary immune functions for their mode of action. Elimination of N-linked glycosylation on the canonical N297 residue reduces $\mathrm{Fc} \gamma \mathrm{R}$ and complement interactions-minimizing the potential for activation of immune effector functions without adversely impacting FcRn binding and plasma half-life (Tao and Morrison, 1989; Simmons et al., 2002; Pyzik et al., 2015; Rath et al., 2015; Jacobsen et al., 2017) or the ability of ALD403 to inhibit binding to CGRP and subsequent inhibition of CGRP signaling. Experiments performed in vitro using both Fc $\gamma \mathrm{R}$ binding and activation assays confirmed the lack of interaction of ALD403 with Fc $\gamma$ receptors. In addition, there was no stimulation of complement-mediated cell cytotoxicity with ALD403.

Capsaicin-induced dermal blood flow is a common, valuable tool for measuring in vivo CGRP-driven neurogenic vasodilation (Hershey et al., 2005; Van der Schueren et al., 2007; Sinclair et al., 2010). Capsaicin activates the transient receptor potential vanilloid type 1 receptor in the blood vessels of the skin, producing neurogenic inflammation and vasodilation via the local release of vasoactive mediators, including CGRP. Capsaicin is applied topically, and changes in the dermal blood flow are measured using a laser Doppler imaging system. The ability of ALD403 to inhibit CGRP-mediated neurogenic vasodilation in the skin of the rat was demonstrated. This finding is consistent with data from approved anti-CGRP mAbs, all of which have demonstrated the ability to inhibit capsaicin-induced vasodilation (Vermeersch et al., 2015; Monteith et al., 2017; Vu et al., 2017).

In conclusion, ALD403 potently binds to the human CGRP peptide, showing species specificity and strong pharmacodynamic activity. These results confirm the utility of the ALD403 mAb as a competitive inhibitor to the CGRP ligand, effectively blocking the CGRP signaling pathway and exhibiting clinical utility in migraine.

\section{Acknowledgments}

The authors thank their colleagues for analytical help and technical input into the studies. The authors thank Philip Sjostedt, BPharm, for 
medical writing, editorial, and graphical support in preparation of this manuscript, which was funded by H. Lundbeck A/S in line with Good Publication Practices.

\section{Authorship Contributions}

Participated in research design: Garcia-Martinez, Raport, Dutzar, Kovacevich, Baker, Allison, Latham.

Conducted experiments: Ojala, Anderson, Stewart, Billgren, Scalley-Kim, Karasek.

Wrote or contributed to the writing of the manuscript: GarciaMartinez, Raport, Ojala, Dutzar, Anderson, Stewart, Kovacevich, Baker, Billgren, Scalley-Kim, Karasek, Allison, Latham.

\section{References}

Almagro JC and Fransson J (2008) Humanization of antibodies. Front Biosci 13: $1619-1633$

Agostoni EC, Barbanti P, Calabresi P, Colombo B, Cortelli P, Frediani F, Geppetti P, Grazzi L, Leone M, Martelletti P, et al.; Italian Chronic Migraine Group (2019) Current and emerging evidence-based treatment options in chronic migraine: a narrative review. $J$ Headache Pain 20:92.

Baker B, Schaeffler B, Cady R, Latham J, Whitaker T, and Smith J (2017) Rational design of a monoclonal antibody ( $\mathrm{mAB}$ ) inhibiting calcitonin gene-related peptide (CGRP), ALD403, intended for the prevention of migraine. Neurology 88 (suppl 16):P2.155.

Bille B (1997) A 40-year follow-up of school children with migraine. Cephalalgia 17: 488-491, discussion 487.

Buzzi MG, Tassorelli C, and Nappi G (2003) Peripheral and central activation of trigeminal pain pathways in migraine: data from experimental animal models. Cephalalgia 23 (Suppl 1):1-4.

Ceriani CEJ, Wilhour DA, and Silberstein SD (2019) Novel medications for the treatment of migraine. Headache 59:1597-1608.

Charles A and Pozo-Rosich P (2019) Targeting calcitonin gene-related peptide: a new era in migraine therapy. Lancet 394:1765-1774.

Dodick DW, Goadsby PJ, Silberstein SD, Lipton RB, Olesen J, Ashina M, Wilks K, Kudrow D, Kroll R, Kohrman B, et al.; ALD403 Study Investigators (2014) Safety and efficacy of ALD403, an antibody to calcitonin gene-related peptide, for the prevention of frequent episodic migraine: a randomised, double-blind, placebocontrolled, exploratory phase 2 trial. Lancet Neurol 13:1100-1107.

Dodick DW, Lipton RB, Silberstein S, Goadsby PJ, Biondi D, Hirman J, Cady R, and Smith J (2019) Eptinezumab for prevention of chronic migraine: a randomized phase 2b clinical trial. Cephalalgia 39:1075-1085.

Dorokhov YL, Sheshukova EV, Kosobokova EN, Shindyapina AV, Kosorukov VS, and Komarova TV (2016) Functional role of carbohydrate residues in human immunoglobulin G and therapeutic monoclonal antibodies. Biochemistry (Mosc) 81:835-857.

Durham PL (2006) Calcitonin gene-related peptide (CGRP) and migraine. Headache 46 (Suppl 1):S3-S8

Edvinsson L (2018a) CGRP antibodies as prophylaxis in migraine. Cell 175:1719.

Edvinsson L (2018b) The CGRP pathway in migraine as a viable target for therapies. Headache 58 (Suppl 1):33-47.

Edvinsson L, Haanes KA, Warfvinge K, and Krause DN (2018) CGRP as the target of new migraine therapies - successful translation from bench to clinic. Nat Rev Neurol 14:338-350.

Ferri N, Bellosta S, Baldessin L, Boccia D, Racagni G, and Corsini A (2016) Pharmacokinetics interactions of monoclonal antibodies. Pharmacol Res 111:592-599.

GBD 2016 Disease and Injury Incidence and Prevalence Collaborators (2017) Global, regional, and national incidence, prevalence, and years lived with disability for 328 diseases and injuries for 195 countries, 1990-2016: a systematic analysis for the Global Burden of Disease Study 2016. Lancet 390:1211-1259.

Hansen JM, Hauge AW, Olesen J, and Ashina M (2010) Calcitonin gene-related peptide triggers migraine-like attacks in patients with migraine with aura Cephalalgia 30:1179-1186.

Hay DL, Christopoulos G, Christopoulos A, and Sexton PM (2006) Determinants of 1 piperidinecarboxamide, N-[2-[[5-amino-l-[[4-(4-pyridinyl)-l-piperazinyl]carbonyl] pentyl]amino]-1-[(3,5-dibromo-4-hydroxyphenyl)methyl]-2-oxoethyl]-4-(1,4-dihydro-2-oxo-3(2H)-quinazolinyl) (BIBN4096BS) affinity for calcitonin gene-related peptide and amylin receptors--the role of receptor activity modifying protein $1 . \mathrm{Mol}$ Pharmacol 70:1984-1991.

Hay DL, Garelja ML, Poyner DR, and Walker CS (2018) Update on the pharmacology of calcitonin/CGRP family of peptides: IUPHAR review $25 . \mathrm{Br} J$ Pharmacol 175 3-17.

Hay DL and Walker CS (2017) CGRP and its receptors. Headache 57:625-636.

Headache Classification Committee of the International Headache Society (2018) The International Classification of Headache Disorders, 3rd edition. Cephalalgia 38:1-211.

Hershey JC, Corcoran HA, Baskin EP, Salvatore CA, Mosser S, Williams TM, Koblan KS, Hargreaves RJ, and Kane SA (2005) Investigation of the species selectivity of a nonpeptide CGRP receptor antagonist using a novel pharmacodynamic assay. Regul Pept 127:71-77.

Hostetler ED, Joshi AD, Sanabria-Bohórquez S, Fan H, Zeng Z, Purcell M, Gantert L, Riffel K, Williams M, O'Malley S, et al. (2013) In vivo quantification of calcitonin gene-related peptide receptor occupancy by telcagepant in rhesus monkey and human brain using the positron emission tomography tracer [11C]MK-4232. $J$ Pharmacol Exp Ther 347:478-486.

Jacobsen FW, Stevenson R, Li C, Salimi-Moosavi H, Liu L, Wen J, Luo Q, Daris K, Buck L, Miller S, et al. (2017) Engineering an IgG scaffold lacking effector function with optimized developability. J Biol Chem 292:1865-1875.
Jones PT, Dear PH, Foote J, Neuberger MS, and Winter G (1986) Replacing the complementarity-determining regions in a human antibody with those from a mouse. Nature 321:522-525.

Koene HR, Kleijer M, Algra J, Roos D, von dem Borne AE, and de Haas M (1997) Fc gammaRIIIa-158V/F polymorphism influences the binding of IgG by natural killer cell Fc gammaRIIIa, independently of the Fc gammaRIIIa-48L/R/H phenotype. Blood 90:1109-1114.

Kuramochi T, Igawa T, Tsunoda H, and Hattori K (2019) Humanization and simultaneous optimization of monoclonal antibody. Methods Mol Biol 1904:213-230.

Lassen LH, Haderslev PA, Jacobsen VB, Iversen HK, Sperling B, and Olesen J (2002) CGRP may play a causative role in migraine. Cephalalgia 22:54-61.

Lightwood DJ, Carrington B, Henry AJ, McKnight AJ, Crook K, Cromie K, and Lawson $\mathrm{AD}$ (2006) Antibody generation through $\mathrm{B}$ cell panning on antigen followed by in situ culture and direct RT-PCR on cells harvested en masse from antigen-positive wells. J Immunol Methods 316:133-143.

Lipton RB, Bigal ME, Diamond M, Freitag F, Reed ML, and Stewart WF; AMPP Advisory Group (2007) Migraine prevalence, disease burden, and the need for preventive therapy. Neurology 68:343-349.

Lipton RB and Silberstein SD (2015) Episodic and chronic migraine headache: breaking down barriers to optimal treatment and prevention. Headache $\mathbf{5 5}$ (Suppl 2):103-122, NaN-126.

Loder E (2010) Triptan therapy in migraine. N Engl J Med 363:63-70.

Lukacs M, Tajti J, Fulop F, Toldi J, Edvinsson L, and Vecsei L (2017) Migraine, neurogenic inflammation, drug development - pharmacochemical aspects. Curr Med Chem 24:3649-3665.

May A and Goadsby PJ (1999) The trigeminovascular system in humans: pathophysiologic implications for primary headache syndromes of the neural influences on the cerebral circulation. J Cereb Blood Flow Metab 19:115-127.

Mayrhofer P and Kunert R (2019) Nomenclature of humanized mAbs: early concepts, current challenges and future perspectives. Hum Antibodies 27:37-51.

Mimura Y, Katoh T, Saldova R, O'Flaherty R, Izumi T, Mimura-Kimura Y, Utsunomiya T, Mizukami Y, Yamamoto K, Matsumoto T, et al. (2018) Glycosylation engineering of therapeutic IgG antibodies: challenges for the safety, functionality and efficacy. Protein Cell 9:47-62.

Monteith D, Collins EC, Vandermeulen C, Van Hecken A, Raddad E, Scherer JC, Grayzel D, Schuetz TJ, and de Hoon J (2017) Safety, tolerability, pharmacokinetics, and pharmacodynamics of the CGRP binding monoclonal antibody LY2951742 (galcanezumab) in healthy volunteers. Front Pharmacol 8:740.

Moore EL and Salvatore CA (2012) Targeting a family B GPCR/RAMP receptor complex: CGRP receptor antagonists and migraine. $\mathrm{Br} J$ Pharmacol 166: $66-78$.

Noseda R and Burstein R (2013) Migraine pathophysiology: anatomy of the trigeminovascular pathway and associated neurological symptoms, cortical spreading depression, sensitization, and modulation of pain. Pain 154 (Suppl 1):S44-S53.

Obermann M and Holle D (2016) Recent advances in the management of migraine. F1000 Res 5:2726.

Parikh SK and Silberstein SD (2019) Preventive treatment for episodic migraine. Neurol Clin 37:753-770.

Pellesi L, Guerzoni S, and Pini LA (2017) Spotlight on anti-CGRP monoclonal antibodies in migraine: the clinical evidence to date. Clin Pharmacol Drug Dev 6: 534-547.

Pietrobon D and Moskowitz MA (2013) Pathophysiology of migraine. Annu Rev Physiol 75:365-391.

Pyzik M, Rath T, Lencer WI, Baker K, and Blumberg RS (2015) FcRn: the architect behind the immune and nonimmune functions of IgG and albumin. J Immunol 194: 4595-4603.

Rath T, Baker K, Dumont JA, Peters RT, Jiang H, Qiao SW, Lencer WI, Pierce GF, and Blumberg RS (2015) Fc-fusion proteins and FcRn: structural insights for longer-lasting and more effective therapeutics. Crit Rev Biotechnol 35:235-254.

Richards JO, Karki S, Lazar GA, Chen H, Dang W, and Desjarlais JR (2008) Optimization of antibody binding to FcgammaRIIa enhances macrophage phagocytosis of tumor cells. Mol Cancer Ther 7:2517-2527.

Russo AF (2015) Calcitonin gene-related peptide (CGRP): a new target for migraine. Annu Rev Pharmacol Toxicol 55:533-552.

Saxena A and Wu D (2016) Advances in therapeutic Fc engineering - modulation of IgG-associated effector functions and serum half-life. Front Immunol 7:580.

Silberstein SD, Holland S, Freitag F, Dodick DW, Argoff C, and Ashman E; Quality Standards Subcommittee of the American Academy of Neurology and the American Headache Society (2012) Evidence-based guideline update: pharmacologic treatment for episodic migraine prevention in adults: report of the Quality Standards Subcommittee of the American Academy of Neurology and the American Headache Society. Neurology 78:1337-1345.

Simmons LC, Reilly D, Klimowski L, Raju TS, Meng G, Sims P, Hong K, Shields RL, Damico LA, Rancatore P, et al. (2002) Expression of full-length immunoglobulins in Escherichia coli: rapid and efficient production of aglycosylated antibodies. $J$ Immunol Methods 263:133-147.

Sinclair SR, Kane SA, Van der Schueren BJ, Xiao A, Willson KJ, Boyle J, de Lepeleire I, Xu Y, Hickey L, Denney WS, et al. (2010) Inhibition of capsaicin-induced increase in dermal blood flow by the oral CGRP receptor antagonist, telcagepant (MK-0974). Br J Clin Pharmacol 69:15-22.

Steiner TJ, Stovner LJ, and Birbeck GL (2013) Migraine: the seventh disabler. $J$ Headache Pain 14:1.

Steiner TJ, Stovner LJ, Vos T, Jensen R, and Katsarava Z (2018) Migraine is first cause of disability in under 50 s: will health politicians now take notice? J Headache Pain 19:17.

Tao MH and Morrison SL (1989) Studies of aglycosylated chimeric mouse-human IgG. Role of carbohydrate in the structure and effector functions mediated by the human IgG constant region. J Immunol 143:2595-2601.

Tepper SJ (2018) History and review of anti-calcitonin Gene-Related Peptide (CGRP) therapies: from translational research to treatment. Headache $\mathbf{5 8}$ (Suppl 3): 238-275. 
Tepper SJ (2019) CGRP and headache: a brief review. Neurol Sci 40 (Suppl 1):99-105 Tilakaratne N, Christopoulos G, Zumpe ET, Foord SM, and Sexton PM (2000) Amylin receptor phenotypes derived from human calcitonin receptor/RAMP coexpression exhibit pharmacological differences dependent on receptor isoform and host cell environment. J Pharmacol Exp Ther 294:61-72.

Van der Schueren BJ, de Hoon JN, Vanmolkot FH, Van Hecken A, Depre M, Kane SA, De Lepeleire I, and Sinclair SR (2007) Reproducibility of the capsaicin-induced dermal blood flow response as assessed by laser Doppler perfusion imaging. $\mathrm{Br}$ $J$ Clin Pharmacol 64:580-590.

Van Valen F, Piechot G, and Jürgens H (1990) Calcitonin gene-related peptide (CGRP) receptors are linked to cyclic adenosine monophosphate production in SKN-MC human neuroblastoma cells. Neurosci Lett 119:195-198.

Vermeersch S, Benschop RJ, Van Hecken A, Monteith D, Wroblewski VJ, Grayzel D, de Hoon J, and Collins EC (2015) Translational pharmacodynamics of calcitonin gene-related peptide monoclonal antibody LY2951742 in a capsaicin-induced dermal blood flow model. $J$ Pharmacol Exp Ther 354:350-357.

Vu T, Ma P, Chen JS, de Hoon J, Van Hecken A, Yan L, Wu LS, Hamilton L, and Vargas G (2017) Pharmacokinetic-pharmacodynamic relationship of erenumab (AMG 334) and capsaicin-induced dermal blood flow in healthy and migraine subjects. Pharm Res 34:1784-1795.
Waldmann H (2019) Human monoclonal antibodies: the benefits of humanization. Methods Mol Biol 1904:1-10.

Walker CS, Eftekhari S, Bower RL, Wilderman A, Insel PA, Edvinsson L, Waldvogel HJ, Jamaluddin MA, Russo AF, and Hay DL (2015) A second trigeminal CGRP receptor: function and expression of the AMY1 receptor. Ann Clin Transl Neurol 2 595-608.

Wimalawansa SJ (1996) Calcitonin gene-related peptide and its receptors: molecular genetics, physiology, pathophysiology, and therapeutic potentials. Endocr Rev 17:533-585

Wimalawansa SJ (1997) Amylin, calcitonin gene-related peptide, calcitonin, and adrenomedullin: a peptide superfamily. Crit Rev Neurobiol 11:167-239.

Wrobel Goldberg S and Silberstein SD (2015) Targeting CGRP: a new era for migraine treatment. CNS Drugs 29:443-452.

Yuan H, Spare NM, and Silberstein SD (2019) Targeting CGRP for the prevention of migraine and cluster headache: a narrative review. Headache $\mathbf{5 9}$ (Suppl 2):20-32

Address correspondence to: Leon F. Garcia-Martinez, Lundbeck Seattle BioPharmaceuticals, Inc., 11804 North Creek Parkway S., Bothell, WA 98011. E-mail: lgarciamtz306@outlook.com 